\title{
Article/Artigo
}

\section{High prevalence of methicillin-resistant Staphylococcus aureus with SCCmec type III in cystic fibrosis patients in southern, Brazil}

\author{
Alta prevalência de Staphylococcus aureus resistente à meticilina com SCCmec tipo III \\ em pacientes com fibrose cística no Sul do Brasil
}

\author{
Keli Cristine Reiter ${ }^{1}$, Alice Beatriz Mombach Pinheiro Machado ${ }^{2}$, Ana Lúcia Peixoto de Freitas ${ }^{3}$ and \\ Afonso Luís Barth ${ }^{1,2}$
}

\begin{abstract}
Introduction: Bacterial colonization of the lungs is the main cause of morbidity in cystic fibrosis (CF). Pathogens such as Staphylococcus aureus are very well adapted to the pulmonary environment and may persist for years in the same patient. Genetic determinants of these bacteria, such as the presence of SCCmec have recently emerged as a problem in this population of patients. Methods: Staphylococcus aureus isolates obtained from different clinical materials coming from $\mathrm{CF}$ and non-CF patients attended at a cystic fibrosis reference hospital were compared according to SCCmec type and antibiotic susceptibility profile. Results: Three hundred and sixty-four single-patient Staphylococcus aureus isolates were collected, of which 164 (45\%) were from CF patients. Among the latter, 57/164 (44.5\%) were MRSA, and among the non-CF patients, $89 / 200$ (35\%) were MRSA. Associated pathogens were found in $38 \mathrm{CF}$ patients. All 57 MRSA from CF patients harbored the multiresistant cassette type III. In contrast, 31/89 MRSA from non-CF patients harbored SCCmec type I (35\%) and 44/89 harbored type III (49\%). The antibiotic susceptibility pattern was similar between CF and non-CF patients. Conclusions: The high prevalence of multiresistant SCCmec type III among CF patients compared with non-CF patients in our institution may make it difficult to control disease progression through antibiotic therapy for promoting the survival of this kind of patient.
\end{abstract}

Key-words: Cystic fibrosis. SCCmec. MRSA. Multiresistance

\section{RESUMO}

Introdução: Colonização pulmonar bacteriana é a principal causa de morbidade em fibrose cística (FC). Patógenos como Staphylococcus aureus são muito bem adaptados ao ambiente pulmonar e podem persistir por anos no mesmo paciente. Determinantes genéticos desta bactéria, como presença de SCCmec emergiram recentemente como um problema nesta população de pacientes. Métodos: Foram comparados isolados de Staphylococcus aureus obtidos de diferentes materiais clínicos, de pacientes com e sem FC atendidos em um hospital de referência em tratamento de fibrocísticos de acordo com o tipo de SCCmec e o perfil de susceptibilidade aos antimicrobianos. Resultados: Foram coletados 364 Staphylococcus aureus, um isolado por paciente, sendo 164 (45\%) de pacientes com FC. Entre estes pacientes, 57/164 (44,5\%) eram MRSA, e entre pacientes não fibrocísticos, MRSA compreendiam 89/200 (35\%). Foram encontrados outros patógenos, associados ao Staphylococcus aureus, em 38 pacientes com FC. Todos 57 MRSA de pacientes com FC possuíam o cassete de multiresistência tipo III. Por outro lado, 31/89 MRSA de pacientes não fibrocísticos possuíam SCCmec tipo I (35\%) e 44/89 possuíam tipo III (49\%). O perfil de susceptibilidade aos antimicrobianos foi similar entre pacientes com e sem FC. Conclusões: A alta prevalência do SCCmec de multiresistência tipo III entre pacientes com FC comparado com pacientes sem FC em nossa instituição pode dificultar o controle da progressão da doença, feito através da antibioticoterapia, e que promove a sobrevivência deste tipo de paciente.

Palavras-chaves: Fibrose cística. SCCmec. MRSA. Multirresistência

1. Medical Sciences Post-Graduate Program, Medicine School, Universidade Federal do Rio Grande do Sul, Porto Alegre, RS, Brazil. 2. Microbiology and Molecular Biology Unit, Hospital de Clínicas de Porto Alegre, Porto Alegre, RS, Brazil. 3. Pharmacy School, Universidade Federal do Rio Grande do Sul, Porto Alegre, RS, Brazil.

Address to: Dra. Keli Cristine Reiter. Laboratório de Pós-Graduação em Patologia/UFSCPA. Rua Sarmento Leite 245, 90050-170 Porto Alegre, RS, Brasil.

Fax: 5551 2101-8607

e-mail: kelir@ufcspa.edu.br

Received in 23/04/2010

Accepted in 14/05/2010

\section{INTRODUCTION}

Chronic pathogenic colonization of the lungs with Pseudomonas aeruginosa and Staphylococcus aureus is the main cause of morbidity in cystic fibrosis $(\mathrm{CF})^{1}$. Recently, increased incidence of methicillin-resistant Staphylococcus aureus (MRSA) infection in CF cases has been demonstrated, but the impact of MRSA detection on clinical outcomes is unclear $^{2,3}$. Nevertheless, MRSA may be the cause of patients' rejection of pulmonary transplants and studies have suggested that patient-to-patient transmission of the different pathogens, including MRSA, may occur ${ }^{4,5}$.

Cystic fibrosis pathogens are well adapted to the CF pulmonary environment and are difficult to eradicate, and Staphylococcus aureus may persist for years in the same patient ${ }^{6}$. In addition to resistance to methicillin, Staphylococcus aureus may also present other genetic determinants that contribute to pathogenicity and virulence, such as hypermutator populations and biofilm production, which make it more difficult to eradicate these pathogens ${ }^{7,8}$. These and other features, such as presence of the $p v l$ gene and SCCmec distribution, have not been well studied in CF patients but have recently been detected as an emerging problem in this population?

The aim of this study was to determine the presence of SCCmec types and the antibiotic susceptibility profile in a MRSA population recovered from CF patients at our institution.

\section{METHODS}

\section{Setting}

Hospital de Clínicas de Porto Alegre (HCPA) is a tertiary care medical center in Porto Alegre, Brazil, with 785 inpatient beds. HCPA is a reference center for cystic fibrosis treatment in Brazil and had cared for 210 patients (130 children or adolescents and 80 adults) at the time of the study. 
Cystic fibrosis patients are attended at any time when an acute exacerbation occurs, or routinely every three months. Patients may elect to be admitted to hospital annually, but hospitalization occurs mainly when there is an exacerbation.

\section{Bacterial isolates}

Staphylococcus aureus isolates from CF and non-CF patients in all clinical settings (hospitalized patients, emergency departments and outpatient care) were compared. All the isolates from CF patients were obtained from the respiratory tract (sputum and oropharyngeal swab). The isolates from non-CF patients were obtained from a variety of clinical specimens, but most of them were also obtained from sputum. The antibiotic susceptibility profile of each isolate was determined using the following antibiotics: gentamicin, doxycycline, levofloxacin, erythromycin, cefoxitin, rifampicin, sulfamethoxazoletrimethoprim, clindamycin and chloramphenicol. All the assays were performed in accordance with the $\mathrm{CLSI}^{10}$. Isolates with intermediate test results were considered to be resistant.

\section{Molecular typing of MRSA isolates}

The presence of the mecA gene was assessed for all Staphylococcus aureus isolates, and the SCCmec type of all positive mecA strains was determined from the molecular architecture of the $\mathrm{ccr}$ and $\mathrm{mec}$ complexes using PCR, as previously described ${ }^{11}$.

\section{Patient information}

For each MRSA patient-isolate, the medical records were reviewed to determine the demographic information, the date of specimen procurement, the anatomical site of the culture, the clinical indication for the culture and the antibiotic susceptibility.

\section{Definitions of CA-MRSA and HA-MRSA}

Patient-isolates were designated as community-acquired (CA) or hospital-acquired (HA) MRSA, based on the SCCmec type. SCCmec type IV isolates were considered to be CA-MRSA, and SCCmec types I, II or III were considered to be HA-MRSA ${ }^{12}$.

\section{RESULTS}

\section{Study population}

A total of 364 single-patient Staphylococcus aureus isolates were selected for the present study. One hundred and four (45\%) isolates were from CF patients, and 57 (44.5\%) of them were MRSA. Among the isolates from non-CF patients, $89 / 200$ (35\%) were MRSA. The majority of the CF patients went to hospital for routine care after an exacerbation had occurred, and 172/200 non-CF patients had an infection during hospitalization for other reasons.

The vast majority of the isolates were from the respiratory tract (239 (65.5\%) isolates, including patients with and without CF). The specimens from CF patients included only sputum or oropharyngeal swabs, while the specimens from non-CF patients also included several other clinical specimens: blood (16.5\%), ascitic fluid (2\%), indwelling catheter (2.5\%), urine (7\%), abscesses and skin secretions (4.5\% and 19\%, respectively), among others (7\%) (Table 1).

For 19 CF patients (33\%) with a MRSA isolate, the specimen was recovered in a pure culture. Associated pathogens in the other 38 patients were $P$. aeruginosa $(\mathrm{n}=26$; Achromobacter xylosoxidans $(\mathrm{n}=6)$; Stenotrophomonas maltophilia $(\mathrm{n}=4)$; Burkholderia cepacea complex ( $\mathrm{n}=4)$; Klebsiella pneumoniae $(\mathrm{n}=2)$; Haemophilus influenzae, Klebsiella oxytoca, methicillin-susceptible S. aureus (MSSA), Serratia sp. and Pseudomonas fluorescens (one each); and other non-fermenting bacilli $(n=3)$. Some patients presented more than one associated pathogen.

\section{Molecular typing of MRSA isolates}

All of the 57MRSA isolates from CF patients harbored SCCmectype III, but one isolate harbored SCCmec type I simultaneously with type III. In contrast, 31/89 MRSA isolates from non-CF patients harbored SCCmec type I (35\%) and 44/89 harbored type III (49\%) (Figure 1). Also, only one isolate harbored type I and III simultaneously.

\begin{tabular}{|c|c|c|c|c|c|c|}
\hline Specimen & Total & mecA + & SCCmec I & SCCmec III & SCCmec I-III & untypeable \\
\hline \multicolumn{7}{|l|}{ Non-CF-patients } \\
\hline abscess & 9 & 0 & NA & NA & NA & NA \\
\hline sputum & 75 & 53 & 20 & 24 & 1 & 8 \\
\hline blood & 33 & 9 & 2 & 3 & 0 & 4 \\
\hline BAL & 8 & 2 & 1 & 1 & 0 & 0 \\
\hline ascitic fluid & 4 & 3 & 0 & 3 & 0 & 0 \\
\hline indwellig catheter & 5 & 4 & 2 & 2 & 0 & 0 \\
\hline skin secretion & 38 & 10 & 3 & 6 & 0 & 1 \\
\hline urine & 14 & 5 & 1 & 4 & 0 & 0 \\
\hline other & 14 & 3 & 2 & 1 & 0 & 0 \\
\hline total & 200 & 89 & 31 & 44 & 1 & 13 \\
\hline \multicolumn{7}{|l|}{ CF patients } \\
\hline sputum & 140 & 54 & 0 & 53 & 1 & 0 \\
\hline oropharingeal swab & 24 & 3 & 0 & 3 & 0 & 0 \\
\hline total & 164 & 57 & 0 & 56 & 1 & 0 \\
\hline
\end{tabular}




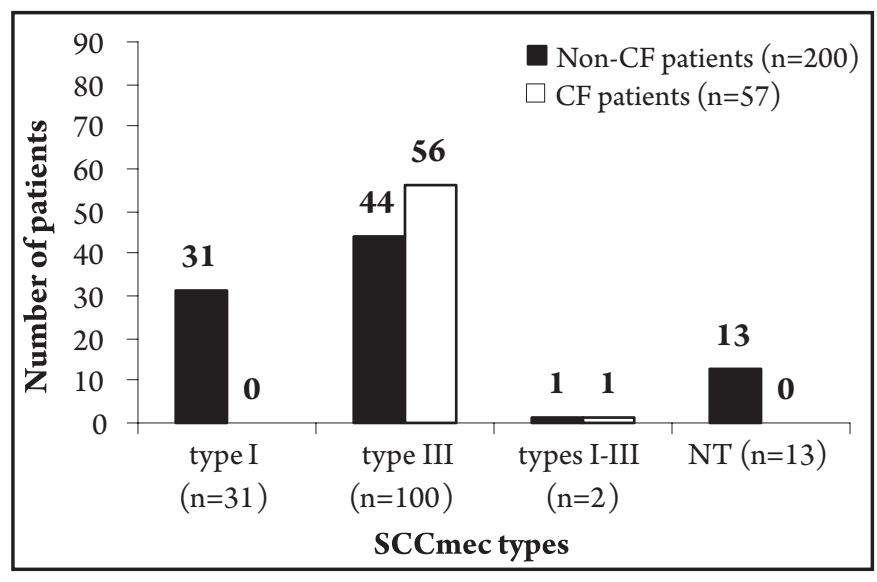

FIGURE 1 - Distribution of SCCmec types between CF and non-CF patients.
Thirteen (15\%) MRSA isolates harbored an untypable SCCmec element, which could not be identified by means of the PCR method used. All of these were obtained from non-CF patients.

It was possible to compare the results regarding SCCmec cassettes according to the clinical specimens from CF versus non-CF patients (i.e. sputum, which was the most prevalent type of specimen). We observed that that the distributions of SCCmec elements I and III were similar, regardless of the clinical specimen (Table 1).

\section{Antimicrobial susceptibility}

All the MRSA isolates underwent antimicrobial susceptibility testing (Table 2). Also, the antibiotic susceptibility of MRSA isolates was compared between those harboring SCCmec type I and those harboring type III (Table 3).

\begin{tabular}{|c|c|c|c|c|c|}
\hline Variables & Total & SCCmec I & SCCmec III & SCCmec I-III & Untypable \\
\hline \multicolumn{6}{|l|}{ CF patients $(n=57)^{b}$} \\
\hline erythomycin & $57 / 57(100)$ & - & $56 / 56(100)$ & $1 / 1(100)$ & - \\
\hline clindamycin & $57 / 57(100)$ & - & $56 / 56(100)$ & $1 / 1(100)$ & - \\
\hline levofloxacin & $47 / 57(82)$ & - & $47 / 56(84)$ & $1 / 1(100)$ & - \\
\hline gentamicin & $54 / 57(95)$ & - & $53 / 56(95)$ & $1 / 1(100)$ & - \\
\hline sulfa-trimethoprim & $56 / 57(98)$ & - & $55 / 56(98)$ & $1 / 1(100)$ & - \\
\hline rifampicin & $40 / 57(70)$ & - & $39 / 56(70)$ & $1 / 1(100)$ & - \\
\hline doxyciclin & $50 / 57(88)$ & - & $49 / 56(87.5)$ & $1 / 1(100)$ & - \\
\hline chloramphenicol & $22 / 57(39)$ & - & $22 / 56(39)$ & $0 / 1(0)$ & - \\
\hline \multicolumn{6}{|c|}{ Non-CF patients $(n=89)^{c}$} \\
\hline erythomycin & 88/89 (99) & $30 / 31(97)$ & $44 / 44(100)$ & $1 / 1(100)$ & $13 / 13(100)$ \\
\hline clindamycin & $84 / 89(94)$ & $30 / 31(97)$ & $40 / 44(91)$ & $1 / 1(100)$ & $13 / 13(100)$ \\
\hline levofloxacin & $79 / 89(89)$ & $26 / 31(84)$ & $40 / 44(91)$ & $1 / 1(100)$ & $12 / 13(92)$ \\
\hline gentamicin & $88 / 89$ (99) & $31 / 31(100)$ & 44/44 (100) & $1 / 1(100)$ & $12 / 13(92)$ \\
\hline sulfa-trimethoprim & $53 / 89(60)$ & $0 / 31(0)$ & $43 / 44(98)$ & $1 / 1(100)$ & $9 / 13(69)$ \\
\hline rifampicin & $37 / 89(42)$ & $0 / 31(0)$ & $32 / 44(73)$ & $0 / 1(0)$ & $5 / 13(39)$ \\
\hline doxyciclin & $36 / 89(40)$ & $0 / 31(0)$ & $30 / 44(68)$ & $0 / 1(0)$ & $6 / 13(46)$ \\
\hline chloramphenicol & $27 / 89(30)$ & 9/31 (29) & $14 / 44(32)$ & $1 / 1(100)$ & $3 / 13(23)$ \\
\hline
\end{tabular}

\begin{tabular}{|c|c|c|c|}
\hline Antibiotic & SCCmec I $^{\mathbf{b}}$ & sCCmec III $^{b}$ & pvalue $^{c}$ \\
\hline clindamycin & $30(96.7)$ & $96(96)$ & NS \\
\hline chloramphenicol & $9(29)$ & $36(36)$ & NS \\
\hline doxycycline & $0(0)$ & $79(79)$ & $<0.001$ \\
\hline erythromycin & $30(96.7)$ & $100(100)$ & NS \\
\hline gentamicin & $31(100)$ & 97 (97) & NS \\
\hline levofloxacin & $26(83.8)$ & $86(86)$ & NS \\
\hline rifampicin & $0(0)$ & $71(71)$ & $<0.001$ \\
\hline sulfa-trimethoprim & $0(0)$ & $98(98)$ & $<0.001$ \\
\hline
\end{tabular}




\section{DISCUSSION}

MRSA isolates are increasingly populating the respiratory tract of CF patients. Hypermutational phenotypes, the ability to form biofilms and high antimicrobial resistance rates have been demonstrated in CF pathogens, and these may be the result from an adaptive process under their special habitat conditions ${ }^{5}$. Millar et al demonstrated that colonization with Pseudomonas aeruginosa or Staphylococcus aureus between 1985 and 2005 remained stable (77 to $82 \%)$, but that MRSA colonization increased ( 1 to $6 \%)^{13}$. Data from the Cystic Fibrosis Foundation Patient Registry in the United States also showed that the prevalence of MRSA increased, from $0.1 \%$ in 1995 to $17.2 \%$ in $2005^{14}$.

This study only characterized Staphylococcus aureus isolates, but it also found the presence of a second or third pathogen in the same patient, in many cases. For $38 \mathrm{CF}$ patients, other pathogens were also identified: Pseudomonas aeruginosa was the most frequent, recovered from 26 CF patients, while Burkholderia cepacea was only recovered in four patients. This low recovery of Burkholderia cepacea may be a reflection of increasing use of single rooms for inpatients who had previously been colonized by this pathogen, in accordance with clinical segregation policies. These procedures have controlled the spread of Burkholderia cepacea among all CF patients attending our hospital.

In our study, there were pathogens that could not be identified, despite recent improvements in microbiological identification techniques; these were classified as non-fermenting bacilli $(\mathrm{n}=3)^{13}$. In addition, we found significantly low prevalence of Haemophilus influenzae $(\mathrm{n}=1)$, which is a very common respiratory pathogen. This was perhaps a result of widespread use of antibiotics such as imipenem and meropenem, which are used to treat Pseudomonas aeruginosa but have concurrent activity against Haemophilus influenzae.

We found remarkable differences between our CF patients and patients with diseases other than CF. All the MRSA isolates from CF patients that we typed were the so-called HA-MRSA strains. These isolates harbored SCCmec type III, which was much more prevalent than in isolates from non-CF patients ( $100 \%$ vs $49 \%$, respectively). Conversely, other studies have shown predominance of SCCmec type I (97\%) or type II (89\%) in CF patients, and also the presence of lower rates of type $\mathrm{IV}^{5,15}$. In order to minimize study bias, we also compared the distribution of SCCmec considering only respiratory specimens. From this, we found that the distribution of SCCmec types was similar, regardless of the origin of the Staphylococcus aureus. This result confirms the high prevalence of SCCmec type III among CF patients in our institution.

The antibiotic susceptibility profile was similar between $\mathrm{CF}$ and non-CF patients, as shown in Table 2. All the isolates harboring SCCmec type III demonstrated high rate of resistance to the antibiotics used in this study, except chloramphenicol. Comparing the MRSA isolates from all the patients, it was found that isolates harboring type III were more resistant to non- $\beta$-lactam antibiotics then were isolates harboring type I. This difference was statistically significant for three antibiotics: trimethoprim/sulfamethoxazole, doxycycline and rifampicin $(\mathrm{p}<0.001)$ (Table 3). In fact, molecular studies have shown that the presence of resistance genes in type III is higher than in type I, although both types of SCCmec are found mostly in hospital-acquired isolates ${ }^{11,12,16}$.
Patients with MRSA have been found to present larger numbers of respiratory exacerbations than do patients with MSSA ${ }^{17}$. Whereas some pathogens detected in CF respiratory cultures are usually transient events, a previous study found that MRSA infection tended to be persistent and confirmed the hypothesis that MRSA is a marker of more severe lung disease ${ }^{2}$. The high prevalence of multiresistant SCCmec type III among the CF patients in our institution, compared with other institutions, may suggest that serious risks exist in relation to treatment of lung colonization and control over disease progression. Until now, antibiotic use has been one of many therapies that have contributed towards improved lung function and ultimately the survival of CF patients. Further studies are necessary to evaluate the possible genetic relatedness between these MRSA isolates.

\section{CONFLICT OF INTEREST}

The authors declare that there is no conflict of interest.

\section{FINANCIAL SUPPORT}

The present study was supported by Fundação de Incentivo à Pesquisa

\section{REFERENCES}

1. Mainz JG, Naehrlich L, Schien M, Kading M, Schiller I, Mayr S, et al. Concordant genotype of upper and lower airways P. aeruginosa and S. aureus isolates in cystic fibrosis. Thorax 2009; 64:535-540.

2. Vergison A, Denis O, Deplano A, Casimir G, Claeys G DeBaets F, et al. National survey of molecular epidemiology of Staphylococcus aureus colonization in Belgian cystic fibrosis patients. J Antimicrob Chemother 2007; 59:893-899.

3. Sawicki GS, Rasouliyan L, Pasta DJ, Regelmann WE, Wagener JS, Waltz DA, et al. The impact of incident methicillin-resistant Staphylococcus aureus detection on pulmonary function in cystic fibrosis. Pediatr Pulmonol 2008; 43:1117-1123.

4. Saiman L, Siegel J. Infection control in cystic fibrosis. Clin Microbiol Rev 2004; 17: 57-71.

5. Molina A, Del Campo R, Máiz L, Morosini MI, Lamas A, Baquero F, et al. High prevalence in cystic fibrosis patients of multiresistant hospital-acquired methicillin-resistant Staphylococcus aureus ST228-SCCmecI capable of biofilm formation. J Antimicrob Chemother 2008; 62:961-967.

6. Kahl BC, Duebbers A, Lubritz G, Haeberle J, Koch HG, Ritzerfeld B, et al. Population dynamics of persistent Staphylococcus aureus isolated from the airways of cystic fibrosis patients during a 6-year prospective study.J Clin Microbiol 2003; 41:4424-4427.

7. Prunier AL, Malbruny B, Laurans M, Brouard J, Duhamel JF, Leclercq R. High rate of macrolide resistance in Staphylococcus aureus strains from patients with cystic fibrosis reveals high proportions of hypermutable strains. J Infect Dis 2003; 187:1709-1716.

8. Garcýa-Castillo M, Morosini MI, Valverde A, Almaraz F, Baquero F, Cantón R, et al. Differences in biofilm development and antibiotic susceptibility among Streptococcus pneumoniae isolates from cystic fibrosis samples and blood cultures. J Antimicrob Chemother 2007; 59:301-304.

9. Elizur A, Orscheln RC, Ferkol TW, Atkinson JJ, Dunne WM, Buller RS, et al Panton-Valentine Leukocidin-positive methicillin-resistant Staphylococcus aureus lung infection in patients with cystic fibrosis. Chest 2007; 131:1718-1725.

10. Wayne PA. Performance standards for antimicrobial susceptibility testing In: Informational Supplement M100-S16. Clinical and Laboratory Standards Institute; 2008.

11. Zhang K, McClure J, Elsayed S, Louie T, Conly JM. Novel multiplex PCR assay for characterization and concomitant subtyping of staphylococcal cassette chromosome mec types I to V in methicillin-resistant Staphylococcus aureus. J Clin Microbiol 2005; 43:5026-5033. 
12. Deurenberg RH, Stobberingh EE. The evolution of Staphylococcus aureus. Infect Gen Evol 2008; 8:747-763.

13. Millar FA, Simmonds NJ, Hodson ME. Trends in pathogens colonising the respiratory tract of adult patients with cystic fibrosis, 1985-2005. J Cyst Fibros 2009; 8:386-391.

14. Razvi S, Quittell L, Sewall A, Quinton H, Marshall B, Saiman L. Respiratory microbiology of patients with cystic fibrosis in the United States, 1995 to 2005. Chest 2009; 136:1554-1560.

15. Goodrich JS, Sutton-Shields TN, Kerr A, Wedd JP, Miller MB, Gilligan PH Prevalence of community-associated methicillin-resistant Staphylococcus aureus in patients with cystic fibrosis. J Clin Microbiol 2009; 47:1231-1233.

16. Ito $\mathrm{T}$, Okuma $\mathrm{K}, \mathrm{Ma} X X$, Yuzawa $\mathrm{H}$, Hiramatsu $\mathrm{K}$. Insights on antibiotic resistance of Staphylococcus aureus from its whole genome: genomic island SCC. Drug Resist Updat 2003; 6:41-52.

17. Girón RM, Buendía B, Pinedo C, Casanova A, Hoyos N, Ancochea J. Methicillinresistant Staphylococcus aureus in patients with cystic fibrosis. Enferm Infec Microbiol Clin 2009; 27:85-88. 